\title{
Determination of Trace and Heavy Metals in Fruit Juices in the Romanian Market
}

\author{
Florin Dumitru BORA ${ }^{1}$, Anamaria CĂLUGĂR ${ }^{2}$, Claudiu Ioan BUNEA ${ }^{2 *}$, Ionut RACZ ${ }^{3}$ \\ ${ }^{1}$ Department of Physico-Chemistry and Biochemistry, Research Station for Viticulture and Enology \\ Târgu Bujoru, Romania \\ ${ }^{2}$ Department of Horticulture and Landscaping, University of Agricultural Sciences and Veterinary \\ Medicine, Cluj-Napoca, Romania \\ ${ }^{3}$ Wheat Breeding Department, Agricultural Research and Development Station Turda, Cluj, Romania \\ *corresponding author: claus_bunea@yahoo.com
}

BulletinUASVM Horticulture 77(2) / 2020

Print ISSN 1843-5254, Electronic ISSN 1843-5394

DOI:10.15835/buasvmcn-hort: 2020.0022

\begin{abstract}
The presence of trace, heavy metals in foodstuffs is of intense public interest. The aim of this study was to determine the metal contents in most known commercial fruit juices present on the Romanian market. The multielement analysis was made using the ICP-MS technique, after appropriate dilution, using the external standard calibration method. Multifruit, mango, and kiwi juice have recoded the highest concentration of $\mathrm{Cu}$, while apple and pear juice has recoded the lowest concentration, and in the case of $\mathrm{Zn}$, peach juice has recoded the highest concentration. Concerning $\mathrm{Pb}, \mathrm{Cd}$, and As concentration, apple, peach, and multifruit juices recorded the highest levels of concentration. The concentration of $\mathrm{Zn}, \mathrm{Cu}, \mathrm{Co}$, and As generally, was higher in the juice samples packed in boxes, while $\mathrm{Ni}, \mathrm{Cr}, \mathrm{Pb}$, and $\mathrm{Cd}$ recorded the highest values in the juice packed in plastic bottles.
\end{abstract}

Keywords: fruit juices, ICP-MS, metal analysis

\section{Introduction}

Food is required by all organisms for the sustenance of life, and its associated functions, such as development, growth, and maintenances of the body. Most food are mainly derived from animals and plants (vegetables, fruits, cereals, and grains) and provide the body with essential resources, such as vitamins and minerals (Adepoju-Bello et al., 2012; Magomya et al., 2015; Izah et al., 2017). Some are consumed without further preparation after purchase (i.g. ready-to-eat food) while others require further processing before consumption. Fruit juice is highly appreciated, tasty food and usually has exceptional nutritional qualities, however, it can be a potential source of toxic elements to nutritional problems due to the low concentration of essential elements, justifying the control of the mineral composition of fruit juice (Dehelean et al., 2013).

The non-alcoholic beverages include many drinks such as carbonated drinks, juices, energy drinks, bottled water, tea, and probiotic drinks, but carbonated drinks and fruit juices represent the largest amount of non-alcoholic beverages, while water and some juices occupy the smallest respectively (Woyessa et al., 2015, Abdel-Rahman et al., 2019). Manufactures of these non-alcoholic beverages should require caution to ensure the purity of constituents used such as raw sources of water and packaging materials which mostly are the sources of contamination in the beverages (Abdel-Rahman et al., 2013, Abdel-Rahman et al., 2019). 
In Romania, the consumption of juices have been steadily growing lately, following trends being also in other European Union countries, especially the consumption of fruit juices have been increased (Dehelean et al., 2013). Commercial fruit juices commonly contain nutrients, minerals, trace elements, phytochemicals, and vitamins all of which have many health benefits when consumed moderately as part of a balanced diet, fruit juices have even a positive effect on promoting health and reducing disease risk (Anastácio et al., 2018).

Trace elements are present in food in a concentration below $50 \mathrm{ppm}$ and have some toxicological or nutritional significance. The macroelements, for example, $\mathrm{Ca}, \mathrm{Mg}, \mathrm{K}$, and $\mathrm{P}$ are fundamental for people, while heavy metals like $\mathrm{As}, \mathrm{Cd}, \mathrm{Pb}$, and $\mathrm{Hg}$ may cause injurious impacts even in low levels of 10-50 ppm. However, $\mathrm{Zn}, \mathrm{Cu}$, and $\mathrm{Fe}$ are found to be necessary in certain quantities in foods, but these elements may be harmful when are ingested in high concentrations. Other nontoxic elements are not unhealthy when present in concentrations beyond 100 ppm ( $\mathrm{Sn}, \mathrm{Cr}, \mathrm{B}, \mathrm{Al}$, and $\mathrm{Ni}$ ). The nonnutritive harmful metals which are known to have deleterious effects even in small levels (below $100 \mathrm{ppm}$ ) are $\mathrm{Cd}, \mathrm{As}, \mathrm{Pb}$, and $\mathrm{Hg}$, consequently, the concentration of both major and trace levels of metals in food is important for both food safety and for nutritional considerations also (Dehelean et al., 2013).

Fruit juice from concentrate is the juice that has been concentrated and returned to its original state by the addition of water. When juice is obtained from a mixture of fruit juices and concentrates, the product label must indicate „partially from concentrates” which must be close to the product name, in the visible text (Rajauria et al., 2018). Concentrate fruit juice is the product obtained from fruit juice by the physical removal of a specific proportion of the water content (normally by evaporation under vacuum). In the production of fruit juice, other than grape, mechanical extraction processes (e.g., pressing) may be combined with the diffusion of pomace (press residue) by water provided that the water extracted soluble solids are added in-line to the primary juice, before the concentration step (Rajauria et al., 2018). Orange and apple juices are the most analyzed types, possibly because they are the most favorite ones and, as a result, the most consumed worldwide. On the other hand, juices obtained from plum, red fruits, and strawberry were not included in many studies. Indeed, it was not possible to find similar studies analyzing red fruits juice or strawberry juice. Consequently, there are no data available for comparison with the results obtained herein.

The aim of this study was to determine the trace of heavy metals in most well known commercial fruit juices present on Romanian market and to compare these results to the maximum admissibe limit set by different international organizations: United States Environmental Protection Agency (USEPA) and World Health Organization (WHO).

\section{Materials and methods}

42 commercial fruit juices (packed in box and plastic bottle) (orange, apple, peach, kiwi, pears, multifruit and mango) purchased from the Romanian market were investigated in this study. For the metal determination in juice, 0.5 $\mathrm{mL}$ juice was digested with $7 \mathrm{~mL}$ of $65 \% \mathrm{HNO}_{3}$ and $1 \mathrm{~mL}$ of $35 \% \mathrm{H}_{2} \mathrm{O}_{2}$ using Milestone START D Digestion System, a microwave system (Bora et al., 2018). After the mineralization process, the samples were filtered through a $0.45 \mu \mathrm{m}$ filter and brought to a volume of $50 \mathrm{ml}$. The method of microwave digestion was optimized in previous work (Bora et al., 2018). The analysis was made using multielement analysis and ICP-MS (iCAP Q Thermo Scientific) technique, after appropriate dilution, using the external standard calibration method. For each sample analysis replicates were measured in order to assure the quality control of our measurements.

\section{Results and discussions}

$\mathrm{Cu}$ and $\mathrm{Zn}$ are essential metals found in the environment, the biological functions of $\mathrm{Cu}$ include cell metabolism, normal iron metabolism, red blood cell (hemoglobin) synthesis, connective tissue metabolism, and bone development (Izah et al., 2017). Multifruit (185.67 $\mu \mathrm{g} / \mathrm{L})$, mango $(192.93 \mu \mathrm{g} / \mathrm{L})$ and kiwi (188.06 $\mu \mathrm{g} / \mathrm{L})$ juice has recoded the highest concentration of $\mathrm{Cu}$, while apple $(83.97 \mu \mathrm{g} / \mathrm{L})$ and pear $(67.07 \mu \mathrm{g} / \mathrm{L})$ juice has recoded the lowest concentration, and in the case of $\mathrm{Zn}$ peach juice has recoded the highest concentration. Concerning $\mathrm{Ni}$ concentration, peach $(66.54 \mu \mathrm{g} / \mathrm{L})$, kiwi $(65.47 \mu \mathrm{g} / \mathrm{L})$, and mango $(67.15 \mu \mathrm{g} / \mathrm{L})$ juice has recoded the highest concentration, regarding the biological function 
Table 1. Concentration of different trace elements in fruit juices (mean $\pm \mu \mathrm{g} / \mathrm{L}$ )

\begin{tabular}{|c|c|c|c|c|c|c|c|c|c|}
\hline Element & Samples & $\mathrm{Cu}$ & $\mathrm{Zn}$ & $\mathrm{Ni}$ & $\mathrm{Cr}$ & Co & $\mathrm{Pb}$ & $\mathrm{Cd}$ & As \\
\hline M.A.L. & (US-EPA, 2018) & 1300 & 5000 & 100 & 100 & 100 & 15 & 5 & 10 \\
\hline M.A.L. & (WHO, 2011) & 2000 & - & 70 & 50 & - & 10 & 3 & 10 \\
\hline \multirow{2}{*}{ Orange } & Box & $144.95 \pm 10.77^{b}$ & $272.90 \pm 12.59^{c}$ & $45.22 \pm 6.16^{c}$ & $7.37 \pm 0.78^{\mathrm{d}}$ & $1.42 \pm 0.65^{\circ}$ & $0.95 \pm 0.30^{\mathrm{g}}$ & $<\mathrm{LOQ}$ & $<\mathrm{LOQ}$ \\
\hline & Plastic & $151.08 \pm 13.77^{b}$ & $226.84 \pm 9.56^{d}$ & $49.81 \pm 5.24^{\mathrm{c}}$ & $7.49 \pm 2.06^{\mathrm{d}}$ & $1.53 \pm 0.32^{\circ}$ & ${ }^{c} 0.63 \pm 0.16^{\mathrm{g}}$ & $<$ LOQ & $<$ LOQ \\
\hline \multirow{2}{*}{ Apple } & Box & $83.97 \pm 5.28^{c}$ & $322.94 \pm 16.78^{b}$ & $28.27 \pm 4.00^{d}$ & $34.39 \pm 6.04^{a}$ & $0.62 \pm 0.11^{\mathrm{d}}$ & $\begin{array}{c}10.71 \pm \\
1.35^{\mathrm{a}} \\
\end{array}$ & $0.25 \pm 0.08^{b}$ & $<\mathrm{LOQ}$ \\
\hline & Plastic & $84.12 \pm 3.96^{c}$ & $319.06 \pm 11.61^{b}$ & $27.29 \pm 6.87^{d}$ & $38.83 \pm 8.54^{a}$ & $<\mathrm{LOQ}$ & $\begin{array}{c}11.06 \pm \\
1.92^{\mathrm{a}}\end{array}$ & $0.18 \pm 0.05^{b}$ & ${ }^{b} 0.16 \pm 0.06^{a}$ \\
\hline \multirow{2}{*}{ Peach } & Box & $142.71 \pm 9.20^{b}$ & $871.73 \pm 5.47^{a}$ & $66.99 \pm 11.30$ & $19.76 \pm 2.35^{b}$ & $<\mathrm{LOQ}$ & $3.99 \pm 0.45^{\mathrm{b} C}$ & $0.26 \pm 015^{b}$ & $<\mathrm{LOQ}$ \\
\hline & Plastic & $144.43 \pm 10.49^{b}$ & $870.93 \pm 15.86^{a}$ & $66.54 \pm 9.75^{a}$ & $21.08 \pm 1.30^{b}$ & $<$ LOQ & $3.21 \pm 1.01^{\mathrm{c}} 0$ & $0.36 \pm 0.01^{a}$ & $<\mathrm{LOQ}$ \\
\hline \multirow{2}{*}{ Kiwi } & Box & $188.06 \pm 6.22^{a}$ & $32.63 \pm 9.04 \mathrm{~g}$ & $65.47 \pm 9.47^{\mathrm{a}}$ & $13.43 \pm 2.52^{c}$ & $2.06 \pm 0.15^{b}$ & ${ }^{b} 1.32 \pm 0.08^{f}$ & $<$ LOQ & $<\mathrm{LOQ}$ \\
\hline & Plastic & $182.73 \pm 11.24^{\mathrm{a}}$ & $36.88 \pm 10.38^{g}$ & $72.83 \pm 5.63^{a}$ & $17.95 \pm 3.85^{b}$ & $2.05 \pm 0.14^{b}$ & b $1.27 \pm 0.08^{f}$ & $<\mathrm{LOQ}$ & $<\mathrm{LOQ}$ \\
\hline \multirow{2}{*}{ Pears } & Box & $71.43 \pm 14.24^{c}$ & $191.54 \pm 8.46^{\mathrm{e}}$ & $15.30 \pm 8.59^{d}$ & $21.02 \pm 1.40^{b}$ & $3.76 \pm 0.62 \mathrm{a}$ & $<\mathrm{LOQ}$ & $<$ LOQ & $<\mathrm{LOQ}$ \\
\hline & Plastic & $67.07 \pm 7.90^{\mathrm{c}}$ & $201.56 \pm 13.02^{\mathrm{e}}$ & $13.85 \pm 4.91^{\mathrm{d}}$ & $24.07 \pm 3.89^{b}$ & $3.68 \pm 0.74^{a}$ & $<\mathrm{LOQ}$ & $<\mathrm{LOQ}$ & $<\mathrm{LOQ}$ \\
\hline \multirow{2}{*}{ Multifuit } & Box & $174.82 \pm 9.55^{a}$ & $192.13 \pm 6.42^{\mathrm{e}}$ & $45.83 \pm 5.29^{c}$ & $7.71 \pm 1.29^{d}$ & $<$ LOQ & $1.99 \pm 0.85^{\mathrm{e}}$ & $<$ LOQ & $0.19 \pm 0.03^{a}$ \\
\hline & Plastic & $185.67 \pm 8.39^{a}$ & $197.39 \pm 11.65^{\mathrm{e}}$ & $51.67 \pm 5.90^{b}$ & $7.19 \pm 2.51^{\mathrm{d}}$ & $<\mathrm{LOQ}$ & $2.43 \pm 0.85^{\mathrm{d}}$ & $<\mathrm{LOQ}$ & $0.17 \pm 0.06^{\mathrm{a}}$ \\
\hline \multirow{2}{*}{ Mango } & Box & $185.47 \pm 6.07^{\mathrm{a}}$ & $61.74 \pm 11.05^{f}$ & $67.15 \pm 9.61^{a}$ & $21.48 \pm 1.61^{b}$ & $0.37 \pm 0.19^{\mathrm{d}}$ & $\mathrm{d} 3.82 \pm 0.58^{\mathrm{b}} \mathrm{C}$ & $0.20 \pm 0.02^{b}$ & $<\mathrm{LOQ}$ \\
\hline & Plastic & $192.93 \pm 16.24^{\mathrm{a}}$ & $69.50 \pm 9.12^{f}$ & $59.07 \pm 14.81$ & ${ }^{\mathrm{b}} 22.32 \pm 2.43^{\mathrm{b}}$ & $0.34 \pm 0.06^{\mathrm{d}}$ & $\mathrm{d} 3.20 \pm 0.08^{\mathrm{c}} 0$ & $0.19 \pm 0.06^{b}$ & $<\mathrm{LOQ}$ \\
\hline
\end{tabular}

Note: Average value \pm standard deviation $(n=3)$. Roman letters represent the significance of the difference (Duncan test, $p<0.05)$. The difference between any two values, followed by at least one common letter, is insignificant. LOQ = lower than the limit of quantification. M.A.L. $=$ maximum admissible limit $(\mu \mathrm{g} / \mathrm{L})$.

of $\mathrm{Ni}$ is still somewhat unclear, it is found in the body in highest concentration in the nucleic acids, particularly RNA, and is thought to be somehow involved in protein structure or function (Kumar et al., 2016). $\mathrm{Cr}$ is one of the toxic essential heavy metals, it is highly detrimental to humans when its concentration exceeds tolerable limits, it aids in the biosynthesis of glucose tolerance factor, utilization of sugar protein and fats (Izah et al., 2017), apple and pear juices have recoded the highest concentration. The results are agreed to those obtained by Abdel-Rahman et al. (2019) who noticed that concentrations of $\mathrm{Cu}$ in carbonated drinks range from $170.00 \mu \mathrm{g} / \mathrm{L} \mathrm{Cu}$ to $0.560 \mu \mathrm{g} / \mathrm{L}$ $\mathrm{Cu}$. Also, Dehelean et al. (2013) and Ofori et al. (2013) revealed that $\mathrm{Cu}, \mathrm{Zn}$ had the highest level in the juice sample as compared to other determined metals. Co is a necessary cofactor for producing the thyroid hormone thyroxin, and also used in anemia treatment causing the red blood cells protection. All the samples studied contained Co concentration bellow the maximum admissible of USEPA (2008) and WHO (2008) (100 $\mu \mathrm{g} / \mathrm{L})$. In the case of $\mathrm{Pb}, \mathrm{Cd}$, and As the highest levels of concentration were recorded in apple (11.06 $\mu \mathrm{g} / \mathrm{L}$ plastic bottle, $10.71 \mu \mathrm{g} / \mathrm{L}$ box $)$, peach $(0.36$ $\mu \mathrm{g} / \mathrm{L})$, and multifruit $(0.19 \mu \mathrm{g} / \mathrm{L}, 0.17 \mu \mathrm{g} / \mathrm{L})$ juice. $\mathrm{Pb}, \mathrm{Cd}$, and As is highly toxic and responsible for several cases of poisoning through food, a low level of Cd causes adverse changes in the arteries of the human kidney (Bora et al., 2018). The analysis of As content reveals the fact that nine fruit juice samples (apple and multifruit) show traces of these heavy metals, while in the rest of the analyzed samples these heavy metals were below the detection limit. The concentration of the metals found in all fruit juices are comparable with the values reported in the literature (Dehelean et al., 2013). Also, Abdel-Rahman et al. (2019) and Abdellseid et al. (2013) studied the level of $\mathrm{Cu}, \mathrm{Cd}$, and $\mathrm{Pb}$ in mango juice from the Libian market, and results were very close to those presented in this study. The concentration of $\mathrm{Zn}, \mathrm{Cu}, \mathrm{Co}$, and As were higher in the juice samples packed in box, while the highest concentration of $\mathrm{Ni}, \mathrm{Cr}, \mathrm{Pb}$, and $\mathrm{Cd}$ were found in the juice samples packed in plastic bottles, the same conclusions were reached by Ofori et al. (2013) and Abdel-Rahman et al. (2019). Also, the level of toxic metals in carbonated drinks depends on the efficiency of the purification processes 
during the production steps, the migration of metals from packaging materials to packed food or drink (Lahimer et al., 2017). A possible explication for the variation in metals content between our tested samples was the type of water used during the production of carbonated drinks in Romania, and also the raw materials and manufacturing process. The variability of metal content between the different juice samples may result from the raw materials, water used in the juice production, the conditions of plant growth such as the toxic metals level in soil, irrigation water, the environmental contaminations (fertilizers and pesticides), purity of the added sugar, and the industrial processing and contamination of containers (Abdel-Rahman et al., 2019). These results are comparable to those reported by Abdel-Rahman et al. (2019) and Hassan et al. (2014) who noticed that $\mathrm{Pb}$ and $\mathrm{Cd}$ were not detected in the most samples of fruit juices.

\section{Conclusion}

This study presents data on the levels of trace and heavy metals in commercial fruit juices (orange, apple, peach, kiwi, pears, multifruit, and mango) present on the Romanian market. Multifruit, mango, and kiwi juice have recoded the highest concentration of $\mathrm{Cu}$, while apple and pear juice has recoded the lowest concentration and in the case of $\mathrm{Zn}$, peach juice has recoded the highest concentration. Concerning $\mathrm{Pb}, \mathrm{Cd}$, and As concentration, apple, peach, and multifruit juices recorded the highest levels and in case of $\mathrm{Cr}$ apple and pears juices have recorded the highest concentration. The concentration of $\mathrm{Zn}, \mathrm{Cu}$, Co and As generally, were higher in the juice samples packed in the box, while $\mathrm{Ni}, \mathrm{Cr}, \mathrm{Pb}$ and $\mathrm{Cd}$ they recorded the highest values in the juice samples packed in plastic bottles. The variability of metal traces between the different juice samples may result from the raw materials, water used in the juice production, the conditions of plant growth such as the used concentration of toxic metals in soil.

Acknowledgments. This paper was published under the frame of the Romanian Ministry of Agriculture and Rural Development, project ADER no. 7.5.5. „Research on the management of alcohol for the production of wine with a low alcohol content".

\section{References}

1. Abdel-Rahman T, Abdellseid AM (2013). Evaluation of heavy metals contamination levels in fruit juices samples collected from El-Beida city, Liban. World Academy of Science Engineering and Technology, 77: 578-580.

2. Abdel-Rahman G, Ahmed MBM, Sabry BA, Ali SSM (2019). Heavy metals content in some non-alcoholic beverages (carbonated drinks, flavoured yogurt drinks, and juice drinks) of Egyptian markets. Toxicology Reports, 6: 210-214.

3. Adepoju-Bello AA, Oguntibeju 00, Onuegbu MT, Ayoola GAA, Coker HAB (2012). Analysis of selected metallic impurities in soft drinks marketed in Logos, Nigeria. African Journal of Biotechnology, 11(20): 4676-4680.

4. Anastácio M, Marreilha dos Santos AP, Aschner M, Mateus $\mathrm{L}$ (2018). Determination of trace metals in fruit juices in the Portoguese market. Toxicology Reports, 5: 434-439.

5. Bora FD, Donici A, Rusu T, Bunea A, Popescu D, Bunea CI (2018). Elemental profile and ${ }^{207} \mathrm{~Pb} /{ }^{206} \mathrm{~Pb},{ }^{208} \mathrm{~Pb} /{ }^{206} \mathrm{~Pb}$, ${ }^{204} \mathrm{~Pb} /{ }^{206} \mathrm{~Pb},{ }^{87} \mathrm{Sr} /{ }^{86} \mathrm{Sr}$ isotope ratios as fingerprints for geographical traceability of Romanian wines. Notulae Botanicae Horti Agrobotanici Cluj-Napoca, 46(1): 223-239.

6. Dehelean A, Magdas DA (2013). Analysis of mineral and heavy metal content in some commercial fruit juices by inductively coupled plasma mass spectrometry. The Scientific World Journal. DOI:10.1155/2013/215423

7. Drinking Water Standards and Health Advisories USA (2018). https://www.epa.gov/sites/production/files/ 2018-03/documents/dwtable2018.pdf.

8. Izah SC, Inyang IR, Angaye TCN, Okowa FP (2017). A review of heavy metal concentration and potential health implication of beverages consumed in Nigeria. Toxics. Doi:10.3390/toxics5010001.

9. Kumar S, Trivedi AV (2016). A review on role of nickel in the biological system. Int J Curr Microbiol App Sci. DOI:org/10.20546/ijcmas.2016.503.084.

10. Lahimer MC, Ayed N, Horriche J, Belgaied S (2017). Characterization of plastic packaging additives: food contact, stability and toxicity. Arabian Journal of Chemistry 10: 1938-1954.

11. Magomya AM, Yebpella GG, Okpaegbe UC (2015). An assessment of metal contaminat level in selected soft drinks sold in Nigeria. International Journal of Innovative Science, Enginnering \& Technology, 2(10): 2108-2114.

12. Ofori H, Owuau M, Anyebuno G (2013). Heavy metals analysis of fruit juice and soft drinks bought from retail market in Accra, Ghana. Journal of Scientific Research and Reports, 2(1): 423-428.

13. Rajauria G, Tiwari BK (2018). Fuit Juices. (1th ed.). London: Academic Press, (Chapter 3).

14. World Health Organization (2011). Guidelines for drinking water quality. Geneva, Switzerland. https://apps.who.int/ iris/bitstream/handle/10665/44584/9789241548151 eng. Pdf; jsessionid=FBFA5C762B8E4C02283E7D26FE9 E5B91? sequence $=1$.

15. Woyessa GW, Kassa SB, Demissie EG (2015). Determination of the level of some trace aand heavy metals in some soft drinks of Ethiopia. Journal of Chemical, Biological and Physical Sciences, 5(2): 2108-2114. 